\title{
Understanding "Culture Shock" As a Bioscience Phenomenon within Intelligence Gathering
}

\author{
Jim Schnell* \\ Fulbright Scholar Association
}

Submission: February 03, 2018; Published: March 22, 2018

*Corresponding author: Jim Schnell, Fulbright Scholar Association, USA, Email: james.schnell@fulbrightmail.org

\section{Introduction}

Culture shock can be a common occurrence and significant detriment within the intelligence gathering process. It is helpful to view such occurrences as a bioscience phenomenon within that intelligence gathering context [1]. That is, the collector can go into a foreign land with the intent of gathering observations addressiing mission objectives that are delineated by policy makers. However, he/she can be confronted, indeed overwhelmed, by culture shock related variables that make it exceedingly difficult for him/her to function.

As international commerce and travel continues to flourish, we frequently find ourselves interacting with individuals who are culturally different from ourselves [2,3]. There are enrichments and frustrations that evolve from such encounters. "Culture shock" is the expression generally associated with the frustrations that occur when we have difficulty functioning in a different culture or when we are exposed to individuals from another culture. Note the latter situation does not necessitate our being in a foreign land. Culture shock can occur in our own hometowns and workplaces [3].

I am a professor of interpersonal communication. Most of my research deals with cross-cultural communication and how the communication process can be improved overall. The field has grown considerably since I completed my Ph.D. in 1982, but the focus on culture shock has been strong and steady since the beginnings of cross-cultural study. Culture shock is a phenomenon with very real and direct consequences but it can be interpreted and understood from a theoretical perspective.

Culture shock typically occurs in a four stage process that can unfold over varying lengths of time: the honeymoon, crisis, resolution and stabilization stages [4-10].

The honeymoon stage exists during our initial intrigue with a place, person and/or perspective that is culturally different (but interesting) to us. It is during this stage that we somewhat rejoice in that which is different. The crisis stage occurs when we are confronted with an event or situation that confuses us to the degree that it becomes a significant obstacle. This confusion can typically lead to frustration and anger. The resolution stage begins when we start to develop a means for dealing with the obstacle encountered in the crisis stage. During this period we develop a resolution mechanism, or approach, that can be used when encountering future obstacles. The stabilization stage is the final period of culture shock when we have resolved the earlier confusion and have achieved a balanced outlook [11-15].

The culture shock stages are exemplified in a situation I experienced early among my visits functioning in China. I have visited China 27 times-where I have served in varied capacities, including university lecturer [15-18].

A. Honeymoon stage: During the early days of my first visit I was elated to be there and was very impressed with the people I met and was especially impressed with the diligence portrayed by my students.

B. Crisis stage: A significant problem arose when I discovered some of my students had plagiarized some of the material they included in their written reports they turned in for my class. That is, they included material authored by someone else without crediting authorship of the material, thus implying they wrote it. I was disturbed by this because they were fine people and I assumed my reporting the incident would result in their removal from the university.

C. Resolution stage: I did report the incident and learned the situation was not perceived to be a problem in China. In the U.S. we stress individual ownership of many things, including ideas. In this case we would expect ideas of others to be footnoted. In China ideas, in this particular scenario, were recognized as belonging to the masses (that is, they belonged to society) and there was not a stringent need to reference a source as directly as we do in the U.S.

D. Stabilization stage: I bridged the U.S. and Chinese approaches for using the work of another person by telling my students if they come to the U.S. they must directly footnote external sources or they will suffer grave consequences. It was not an issue for me after that. 
Cultural norms continually change. The aforementioned incident occurred in 1987 and such plagiarism, that existed in China then, would not occur today. The increased linkages among cultures has made for more unified practices across cultures. As indicated earlier you don't have to leave the U.S. to experience culture shock. I have taught as a professor at the university level in central Ohio and have encountered culture shock experiences similar to the aforementioned incident. Such culture shock events are more common as the number of international students increases. In the military context culture shock can occur in training situations that involve participants from different cultural backgrounds. I experienced culture shock in such a training situation that included Iranians during the summer of 1978 at a U.S. military installation (roughly a year before the 1979 Iranian revolution that resulted in U.S. and Iranian tensions).

E. Honeymoon stage: I lived next door to two Iranians, Ahmad and Yahdi, in base housing. We were attending the same school and I enjoyed learning about their culture during idle hours in the evening and on weekends [16-21].

F. Crisis stage: One evening, after I returned from the library, I smelled an unusual odor coming from the bathroom that Ahmad and I shared. The bathroom was located between our bedrooms and we each had an entrance to the bathroom. There was also loud obnoxious music coming from his room. I entered the bathroom and found the sink and bathtub contained what I can best describe as smelly food scraps. They smelled very bad. I opened his door and found he and Yahdi were preparing a large meal and had some unappealing (to my ears) music blaring. I had planned to shave, shower and study the rest of the evening but this situation stopped me in my tracks. They were oblivious to my concerns about the smell and sound. I considered moving to another room but was aware our building was full. I shaved at a sink in the janitor's closet, got no shower, was not able to study because of the music, and had trouble sleeping because of the smell. I was tired and irritable the next day and didn't speak to them.

G. Resolution stage: I noticed the next evening that the bathroom was clean and there was no loud music playing in Ahmad's room. Late in the evening I saw Ahmad in the hallway and he acted as if the previous evening's confusion had not occurred. As I visited with him I realized the confusion had not occurred for him. He was unaware of my anger until I explained my perception of the situation. He explained it was some type of holy day for them and that it was common for them to engage in that behavior during such days. I was comforted to know it would not happen often.

H. Stabilization stage: I asked Ahmad to give me advance notice before unusual events, such as what I had encountered in the aforementioned incident, occurred in the future. This would allow me to plan accordingly and avoid disruption. He honored my request. It turned out to be a learning experience as I learned a little about their holy days and how they observed them.

The key to successfully dealing with culture shock rests with being able to recognize the stages of culture shock as you experience them. This will allow you to be more rationale in your responses to what you encounter. If you experience frustration but can rationally understand why you are frustrated this can help reduce the anxiety.

During a visit to Senegal (west Africa) I became fearful when I perceived many people were staring at me. I interpreted their stares as being a threat until I thought about the situation and realized I was the only white person in the area I was visiting and I was dressed different than they were. It was understandable for them to be curious about me.

Recognizing culture shock won't make it totally disappear but, like many problems, recognition is the first step toward understanding. Once you understand the shock in "culture shock" you can change it from a frustrating experience to a learning experience.

\section{References}

1. Adler R, Rosenfeld, Proctor R (2012) Interplay, Oxford University Press, New York, USA.

2. Barker L (2017) Listening Behavior. Englewood Cliffs, Prentice-Hall, New Jersey, USA.

3. Canary D, Cody M (2008) Interpersonal Communication, Martin's Press, New York, USA.

4. Davies P (2015) American Heritage Dictionary. Bartleby Publishers, New York, USA.

5. Devito J (2016) The Interpersonal Communication Book. Upper Saddle River, Pearson Publishers, New Jersey, USA.

6. Ehninger D, Gronbeck B, McKerrow R, Monroe A (2006) Principles and Types of Speech Communication. Needham Heights, Massachusetts: Allyn and Bacon, USA.

7. Fitzgerald F (2002) Fire in the Lake: The Vietnamese and Americans in Vietnam. Boston: Bay Back Books, USA.

8. Hall E (1990) The Hidden Dimension. Doubleday, New York, USA.

9. Hayton B (2010) Vietnam: Rising Dragon. New Haven, Connecticut: Yale University Press, USA.

10. House J (1988) People Who Need People. Psychology Today. p. 8.

11. Kalb M (2011) Haunting Legacy: Vietnam and the American Presidency from Ford to Obama. Brookings Institution Press, Washington, USA.

12. Kiernan B (2017) Vietnam: A History from Earliest Times to the Present. Oxford University Press, New York, USA.

13. Knapp M, Hall J, Horgan T (2014) Nonverbal Communication in Human Interaction. Belmont, Wadsworth Publishing, USA.

14. Littlejohn S, Foss K (2011) Theories of Human Communication. Belmont, Wadsworth Publishing, California, USA.

15. Masterson J, Beebe S, Watson N (2009) Speech Communication: Theory and Practice. Holt, Rinehart, and Winston, New York, USA. 
16. Pearson J, Nelson P (2012) Understanding and Sharing. Boston, McGraw-Hill, Massachusetts, USA.

17. Rahim M (2011) Managing Conflict in Organizations. New Brunswick. Transaction Publishers, New Jersey, USA.

18. Rubin R, Perse E, Barbato (1988) Conceptualization and Measurement of Interpersonal Communication Motives. Human Communication Research 14: 602-628.

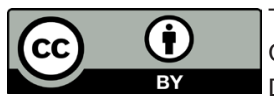

This work is licensed under Creative Commons Attribution 4.0 License DOI: $10.19080 / C T B E B .2018 .13 .555857$
19. Stevens S (1950) A Definition of Communication. The Journal of the Acoustical Society of America 22: 689-690.

20. Trenholm S, Jensen A (2011) Interpersonal Communication. Oxford University Press, New York, USA.

21. Young M (1991) The Vietnam Wars. Harper Collins, New York, USA.

Your next submission with Juniper Publishers
will reach you the below assets
- Quality Editorial service
- Swift Peer Review
- Reprints availability
- E-prints Service
- Manuscript Podcast for convenient understanding
- Global attainment for your research
- Manuscript accessibility in different formats
( Pdf, E-pub, Full Text, Audio)
- Unceasing customer service
Track the below URL for one-step submission
https://juniperpublishers.com/online-submission.php

